\title{
Response of Rice (Oryza sativa) to the Application of Manganese in Makurdi, Benue State, Nigeria
}

\author{
F. Ibrahim*, S.I. Anebi, Alogakho P. Michael
}

Department of Soil Science, Federal University of Agriculture, Makurdi, Benue State, Nigeria

*Correspondence: ibrahimfriday07@gmail.com

Keywords: Fertilizer, Manganese, $\mathrm{MnSO}_{4}$, Rice, Yield.

\begin{abstract}
A pot experiment was carried out at the Agronomy Teaching and Research Farm of the University of Agriculture Makurdi to determine the effect of manganese fertilizer on the growth and yield of rice. Treatment consists of five levels of Manganese $(\mathrm{Mn})\left(0,5,10,15\right.$ and $\left.20 \mathrm{~kg} \mathrm{ha}^{-1}\right)$ in form of $\mathrm{MnSO}_{4}$. The treatments were laid out in a Completely Randomized Design (CRD) with three replications. The effect of $\mathrm{Mn}$ on the growth of rice indicate that there were no significant difference in the growth parameters measured with the exception of plant height at 8 weeks after planting and number of tillers at 4 weeks after planting. The tallest plants and highest number of tillers were obtained with $10 \mathrm{~kg} \mathrm{ha}^{-1} \mathrm{Mn}$. The effect of $\mathrm{Mn}$ on the yield of rice indicate that there was a significant difference in the yield parameters measured with the exception of number of grain per panicle and root weight at 4 weeks after planting. Manganese at the rate of $10 \mathrm{~kg} \mathrm{ha}^{-1}$ gave the highest grain yield $\left(2,667 \mathrm{~kg} \mathrm{ha}^{-1}\right)$ and highest dry matter weight. Levels of Mn above $10 \mathrm{~kg} \mathrm{ha}^{-1}$ led to yield decrease, therefore application of $10 \mathrm{~kg} \mathrm{ha}^{-1} \mathrm{Mn}$ was recommended for optimum yield of rice.
\end{abstract}

\section{Introduction}

Micronutrients are chemical elements necessary for plant growth in only extremely small amount. Although required in minute quantities, they have the same agronomic importance as macronutrients and play vital roles in the growth of plants [1]. These metallic chemical elements include Zinc ( $\mathrm{Zn}$ ), Iron (Fe), Copper (cu) and manganese ( $\mathrm{Mn}$ ), amongst others. Micronutrients improve the yield and the crop quality for cereals, corn, beans, forages, and oil seed [2]. The deficiency of micronutrients reduces performance and profitability in the plant [3].

Manganese is one of the main micronutrients, which plays important role in plant as a component of enzymes involved in photosynthesis and other processes. Manganese is part of an important antioxidant (superoxide dismutase) structure that protects plant cells by deactivating free radicals which can destroy plant tissue. It plays vital roles in photosynthesis, as a structural component of the Photosystem II water splitting protein. It also serves as electron storage and delivery to the chlorophyll reaction centers $[4,5]$.

Rice (Oryza sativa) is a staple food in many countries of Africa and other parts of the world. This is the most important staple food for about half of the human race [6]. Saka and Lawal [7] classified rice as the most important food depended upon by over 50 percent of the World population for about 80 percent of their food need. Due to the growing importance of the crop, FAO [8] estimated that annual rice production should be increased from 586 million metric tons in 2001 to meet the projected global demand of about 756 million metric tons by 2030 .

The drive towards self-sufficiency in food production through the adoption of more scientific intensive agricultural systems has necessitated the evaluation of the nutrient status of soils and their role in crop production; most especially the micronutrients which had hitherto been neglected [9].

However, few investigations carried out so far have revealed micronutrient deficiency in some Nigerian savanna soils [10-12]. These deficiencies may have resulted from intensively cultivated soil with high nutrient-demanding crops, highly weathered rocks and leaching. Mustapha and Loks [13] reported that the use of new high yielding crop varieties which are nutrient demanding have unraveled micronutrient deficiencies in some Nigeria Savanna soils. Also the non-inclusion of these 
important elements (Mn) in fertilization programs have led to its widespread deficiency hence, the need to assess the response of crops to the application of these nutrients, particularly Manganese which facilitates the production of carbohydrates and is required for optimum utilization of macro nutrients in plants.

The present research was undertaken to determine the growth and yield response of rice to the application of Manganese fertilizer.

\section{Materials and Methods}

The present investigation was in two parts; laboratory studies and pot experiment which were carried out in 2017. The laboratory studies include routine soil analysis and micronutrient determination and were carried out at the Advanced Analytical Soil Laboratory of the Department of Soil Science, University of Agriculture, Makurdi while the pot experiment was carried out at the Agronomy Teaching and Research Farm of the same institution which lies between Latitude $7^{\circ} 47^{\prime} \mathrm{N}$ and Longitude $8^{0} 36^{\prime} \mathrm{E}$ at an elevation of $82 \mathrm{~m}$ above sea level.

\section{Soil Sampling and Analysis}

Surface Soil samples were taken at a depth of 0-20 $\mathrm{cm}$ from Agronomy Teaching and Research Farm, Federal University of Agriculture Makurdi, taking into consideration all possible precautions prescribed for soil sampling [14]. The samples were brought to the laboratory, air dried and mixed together thoroughly and crushed to pass a $2 \mathrm{~mm}$ sieve.

\section{Sample Analysis}

The soil samples were analysed for the following parameters using standard procedures; $\mathrm{pH}$ was measured by glass electrode in a 1: 2 soil, water ratio. Exchange acidity was determined by the titration method [15]. Exchangeable bases were extracted with neutral ammonium acetate solution buffered at $\mathrm{pH}$ 7. $\mathrm{Na}$ and $\mathrm{K}$ in the extract were determined using flame photometer while $\mathrm{Ca}$ and $\mathrm{Mg}$ were determined by Atomic Absorption Spectrophotometer (AAS) [15]. Organic matter was determined by wet acid digestion [16], Total Nitrogen by the Kjeldahl digestion method, phosphorus by Bray-1 procedure [17] particle size analysis by the hydrometer method of Bouyoucos [18]. The CEC was determined by neutral, 1N Ammonium acetate method while Base Saturation was calculated by dividing the sum of exchangeable bases by CEC and multiplying by 100. Mn was extracted using $0.1 \mathrm{~N} \mathrm{HCl}$ and read with atomic absorption spectrophotometer. The DTPA extractant was used to extract available micronutrients and the values read on an Atomic Absorption Spectrophotometer [19].

\section{Pot Experiment}

A pot experiment was conducted at the Teaching and Research Farm of the University of Agriculture Makurdi, North Core using soil collected from the farm. Four (4) $\mathrm{kg}$ of the soil was weighed into perforated plastic pots of 5 litres capacity.

Treatment consists of five levels of $\mathrm{Mn}\left(0,5,10,15\right.$ and $\left.20 \mathrm{~kg} \mathrm{ha}^{-1}\right)$ in the form of $\mathrm{MnSO}_{4}$ which contains $27 \% \mathrm{Mn}$. The treatments were laid out in a Completely Randomized Design (CRD) with three replications. Ten (10) seeds of rice (L 34 variety) obtained from Olam rice farm, Rukubi Nasarawa state, Nigeria were planted per pot and later thinned to 5 plants per pot two weeks after planting. Fertilizer equivalent to $80 \mathrm{~kg} \mathrm{~N}, 30 \mathrm{~kg} \mathrm{P}_{2} \mathrm{O}_{5}$ and $\mathrm{K}_{2} \mathrm{O}$ were applied to all the pots as basal application [20] and the $\mathrm{Mn}$ rates distributed accordingly to the pots at planting with the control treatment pots having no Mn application.

\section{Data Collection}

Data was collected on the following parameters:

i. $\quad$ Number of tillers at 4 and 6 weeks after planting

ii. Plant height at 4, 6, 8 and 10 weeks after planting

iii. Root weight at 4, 6 and 8 weeks after planting 
iv. Leaf area at 4, 6, 8 and 10 weeks after planting

v. Number of grains per panicle at harvest

vi. Grain yield at harvest

\section{Data Analysis}

All the plant data collected were subjected to statistical analysis of variance (ANOVA) for the determination of significant treatment effects. Those that have significant effects were separated using Fisher's Least Significant Difference (FLSD).

\section{Results and Discussion}

\section{Physical and Chemical Properties of the Experimental Soil}

The physical and chemical properties of the experimental soils are presented in Table 1 . The pH was slightly acidic (6.29), Textural class was clay loam with $56 \mathrm{~g} \mathrm{~kg}^{-1}$ sand, $36 \mathrm{~g} \mathrm{~kg}^{-1}$ silt and $74 \mathrm{~g} \mathrm{~kg}^{-1}$ clay. The soil was generally low in Phosphorus (3.54 mg kg-1), Calcium (3.33 $\left.\mathrm{cmol} \mathrm{kg}^{-1}\right)$, Magnesium (1.36 $\left.\mathrm{cmol} \mathrm{kg}^{-1}\right)$, Potassium $\left(0.12 \mathrm{cmol} \mathrm{kg}^{-1}\right)$ and Sodium $\left(0.36 \mathrm{cmol} \mathrm{kg}{ }^{-1}\right)$. The Nitrogen content was also very low $(0.02 \%)$. Organic matter was $3.08 \%$, the CEC was low with base saturation of $84 \%$. The micronutrient status of the soil include; Copper which was medium $\left(0.72 \mathrm{mg} \mathrm{kg}^{-1}\right)$, iron was medium $\left(3.5 \mathrm{mg} \mathrm{kg}^{-1}\right)$, Manganese was low $\left(0.70 \mathrm{mg} \mathrm{kg}^{-1}\right)$ and the Zinc content was low $\left(0.02 \mathrm{mg} \mathrm{kg}^{-1}\right)$.

The soil used for this research had low fertility status and was slightly acidic in nature. This could be due to the removal of basic cations from the surface of the soils to the lower depths [13, 22-23]. Results show that organic carbon content was high [23] this is contrary to the low organic carbon values reported by Yaro et al. [24] for the Nigerian Savanna soils, and those reported by Mustapha and Nnalee [25] and Mustapha et al. [26] for soils in the Northern Guinea Savanna Zone of Nigeria.

Table 1. Physical and Chemical Properties of the Soil Under Study

\begin{tabular}{lc}
\hline Parameters & Values \\
\hline $\mathrm{pH}(1: 1)$ & 6.29 \\
Sand $\left(\mathrm{g} \mathrm{kg}^{-1}\right)$ & 56 \\
$\mathrm{Silt}\left(\mathrm{g} \mathrm{kg}^{-1}\right)$ & 36 \\
Clay $\left(\mathrm{g} \mathrm{kg}^{-1}\right)$ & 74 \\
Textural class & Clay Loam \\
Organic C $(\%)$ & 1.79 \\
Organic matter $(\%)$ & 3.08 \\
$\mathrm{~N}(\%)$ & 0.02 \\
Available P $\left(\mathrm{mg} \mathrm{kg}^{-1}\right)$ & 3.54 \\
$\mathrm{Ca}\left(\mathrm{cmol} \mathrm{kg}^{-1}\right)$ & 3.33 \\
$\mathrm{Mg}\left(\mathrm{cmol} \mathrm{kg}^{-1}\right)$ & 1.36 \\
$\mathrm{~K}\left(\mathrm{cmol} \mathrm{kg}^{-1}\right)$ & 0.12 \\
$\mathrm{Na}\left(\mathrm{cmol} \mathrm{kg}^{-1}\right)$ & 0.36 \\
$\mathrm{CEC}\left(\mathrm{cmol} \mathrm{kg}^{-1}\right)$ & 5.17 \\
$\mathrm{~B} . \mathrm{S}(\%)$ & 84 \\
$\mathrm{Exch} \mathrm{A}$ & 0.83 \\
$\mathrm{Cu}\left(\mathrm{mg} \mathrm{kg}^{-1}\right)$ & 0.72 \\
$\mathrm{Fe}(\mathrm{mg} \mathrm{kg}$ & 3.50 \\
$\mathrm{Mn}\left(\mathrm{mg} \mathrm{kg}^{-1}\right)$ & 0.70 \\
$\mathrm{Zn}\left(\mathrm{mg} \mathrm{kg}^{-1}\right)$ & 0.22 \\
\hline
\end{tabular}


The high organic carbon content could be due to the fact that plant residues where usually left on the soil after harvest year after year without burning. The decomposition of these residues may have contributed to the high organic carbon content.

The $\mathrm{Zn}$ level in the soils was low $\left(0.02 \mathrm{mg} \mathrm{kg}^{-1}\right)$ [23]. The values recorded for the soil falls below the 1.2-4.0 $\mathrm{mg} \mathrm{kg}^{-1}$ reported by Kparmwang and Malgwi [27] for the soils in the Northern Guinea Savanna of Nigeria, 0.81 to $1.34 \mathrm{mg} \mathrm{kg}^{-1}$ reported for Ustults in Galambi District in Bauchi State, Nigeria [28] and 1.1 to $6.9 \mathrm{mg} \mathrm{kg}^{-1}$ reported for volcanic ash soils elsewhere in Tanzania [29]. It is pertinent to note that the $\mathrm{Zn}$ values obtained in this study fall below the critical $0.90 \mathrm{mg} \mathrm{kg}^{-}$ ${ }^{1}$ given by Lombin [11]. The low $\mathrm{Zn}$ content may be due to the non-inclusion of micronutrients in fertilizer programs which may lead to its deficiency as reported by Nziguheba et al. [30].

The low value of $\mathrm{Cu}\left(0.72 \mathrm{mg} \mathrm{kg}^{-1}\right)$ obtained in this research is lower than the results obtained by Mustapha and Singh [28] for soils elsewhere in Galambi, Bauchi State, Nigeria in similar AgroEcology but are similar to the 0.81 to $0.26 \mathrm{mg} \mathrm{kg}^{-1}$ obtained by Mustapha et al. [31] in Gombe State. The low $\mathrm{Cu}$ content may be due to increased use of high analysis NPK fertilizers containing no or lower quantities of micronutrient.

The Fe in the soils was low $\left(3.5 \mathrm{mg} \mathrm{kg}^{-1}\right)$. These values are much higher than the critical value (2.5 $\mathrm{mg} \mathrm{kg}^{-1}$ ) reported by Esu [23], but lower to the $12.40-45.1 \mathrm{mg} \mathrm{kg}^{-1}$ reported by Mustapha and Singh [28] for Ustults in similar agro ecology in Nigeria.

The available $\mathrm{Mn}$ in the soil is low $\left(0.7 \mathrm{mg} \mathrm{kg}^{-1}\right)$. This implies that the soils contain $\mathrm{Mn}$ below the critical available range of 3 to $5 \mathrm{mg} \mathrm{kg}^{-1}$ reported by Lindsay and Norvell [19] and $1-5 \mathrm{mgkg}^{-1}$ reported by Esu [23]. The values obtained for these soils is below those obtained for some Ustults in Bauchi, Nigeria (7.89-12.00 $\mathrm{mgkg}^{-1}$ ) reported by Kparmwang [32] in similar Nigerian soils.. The low content of available $\mathrm{Mn}$ in the soils may have resulted from intensive cultivation of the soil with new high nutrient-demanding crops as reported by Mustapha and Loks [13]. These crops remove micronutrients $(\mathrm{Mn})$ from the soil without been replaced which may lead to its depletion.

\section{Effect of Manganese on the Growth of Rice}

The effect of $\mathrm{Mn}$ on the growth of rice (Table 2) indicate that there were no significant difference in the growth parameters measured with the exception of plant height at 8 weeks after planting and number of tillers at 4 weeks after planting.

At 8 weeks after planting, the tallest plants $(5.63 \mathrm{~cm})$ were obtained with $10 \mathrm{~kg} \mathrm{ha}^{-1} \mathrm{Mn}$ however this was not significantly different from plants obtained with $5 \mathrm{~kg} \mathrm{ha}^{1}$ but was significantly taller than plants obtained with 0,15 and $20 \mathrm{~kg} \mathrm{ha}^{-1} \mathrm{Mn}$, which were not significantly different from themselves.

The highest number of tillers (3.67) was obtained with $10 \mathrm{~kg} \mathrm{ha}^{-1} \mathrm{Mn}$ at 4 weeks after planting which was significantly higher from the other treatments but there was no significant difference in number of tillers obtained with $0,5,15$ and $20 \mathrm{~kg} \mathrm{ha}^{-1} \mathrm{Mn}$.

No significant variation in growth parameters were noticed by the application of manganese $(\mathrm{Mn})$ with the exception of plant height at 8 weeks after planting and number of tillers at 4 weeks after planting. This may be due to application manganese in the soil as reported by Qin [33] that rice responds to high $\mathrm{Mn}$ (about $0.5 \mathrm{mg} / \mathrm{L}$ ) application with higher plant height, root length, and contents of chlorophyll a and chlorophyll $b$ than at low Mn level. This is in contrast to reports by Prashad et al. [34] and Shanmugam and Veeraputran [35] that further increase in Mn rate was found to reduce the growth attributes with the minimum being observed in control.

The application of manganese significantly increased number of tillers only at 4 weeks after planting than without manganese this may be due to addition of $\mathrm{Mn}$, this is similar to result obtained by Mousavi [36] who reported that rice fertilized with manganese at 4 weeks after planting had more productive tiller than without manganese this may be presumably caused by manganese which increased the content of chlorophyll in leaves of rice. Manganese played an important role in the production of chlorophyll and its presence was very important in photosynthesis [36] 


\section{Effect of Mn Fertilization on the Yield of Rice}

The effect of Mn on the yield of rice (Table 3) indicated that there were no significant difference in the yield parameters measured with the exception of dry matter weight (DMW), grain yield and root weight (RW) at 8 weeks after planting.

The highest Dry matter weight $(1.67 \mathrm{~g})$ was obtained with $10 \mathrm{~kg} \mathrm{ha}^{-1} \mathrm{Mn}$ but there was no significant difference between 10 and $15 \mathrm{~kg} \mathrm{ha}^{-1} \mathrm{Mn}$. However $10 \mathrm{~kg} \mathrm{ha}^{-1} \mathrm{Mn}$ was significantly different from what was obtained from the other treatments but no significant difference in the dry matter weight obtained with 0,5 and $20 \mathrm{~kg} \mathrm{ha}^{-1} \mathrm{Mn}$.

The highest grain yield $(2,667 \mathrm{~kg})$ per hectare was obtained with $10 \mathrm{~kg} \mathrm{ha}^{-1} \mathrm{Mn}$. However, this was significantly different from what was obtained with the other treatments. There was no significant difference in the grain yield obtained with $0,5,15$ and $20 \mathrm{~kg} \mathrm{ha}^{-1} \mathrm{Mn}$.

Table 2. Effect of Mn Fertilizer on the Growth of Rice

\begin{tabular}{|c|c|c|c|c|c|c|c|c|c|c|}
\hline \multirow{2}{*}{$\begin{array}{c}\text { Treatment } \\
\text { Mn }\end{array}$} & \multicolumn{4}{|c|}{$\begin{array}{l}\text { Plant height } \\
\text { (cm) }\end{array}$} & \multicolumn{2}{|c|}{ Number Tillers } & \multicolumn{4}{|c|}{$\begin{array}{l}\text { Leaf Area } \\
\left(\mathrm{cm}^{2}\right)\end{array}$} \\
\hline & 4WAP & $6 \mathrm{WAP}$ & 8WAP & 10WAP & 4WAP & $6 \mathrm{WAP}$ & 4WAP & $6 \mathrm{WAP}$ & $8 \mathrm{WAP}$ & $10 \mathrm{WAP}$ \\
\hline $0 \mathrm{~kg} \mathrm{ha}^{-1}$ & 34.70 & 42.90 & 44.80 & 51.50 & 3.00 & 3.67 & 8.17 & 11.07 & 13.07 & 16.50 \\
\hline $5 \mathrm{~kg} \mathrm{ha}^{-1}$ & 34.50 & 46.70 & 48.00 & 48.20 & 3.00 & 3.00 & 7.43 & 10.30 & 12.30 & 14.20 \\
\hline $10 \mathrm{~kg} \mathrm{ha}^{-1}$ & 39.20 & 51.10 & 53.60 & 55.30 & 3.67 & 3.67 & 6.73 & 8.83 & 12.33 & 13.23 \\
\hline $15 \mathrm{~kg} \mathrm{ha}^{-1}$ & 32.30 & 42.20 & 44.20 & 46.60 & 3.00 & 3.33 & 9.53 & 13.23 & 15.07 & 16.00 \\
\hline $20 \mathrm{~kg} \mathrm{ha}^{-1}$ & 33.70 & 42.50 & 43.50 & 43.90 & 3.00 & 3.67 & 7.20 & 11.03 & 11.37 & 12.30 \\
\hline $\mathrm{LSD}(\mathrm{P}<0.05)$ & NS & NS & 7.75 & NS & 0.47 & $\mathrm{NS}$ & NS & NS & NS & $\mathrm{NS}$ \\
\hline
\end{tabular}

WAP $=$ Weeks after planting, NS = Not significant

Table 3. Effect of Mn fertilizer on Yield of Rice

\begin{tabular}{cccccc}
\hline Mn & $\begin{array}{c}\text { DMW } \\
(\mathrm{g})\end{array}$ & NGPP & $\begin{array}{c}\text { RW4WAP } \\
(\mathrm{g})\end{array}$ & RW8WAP(g) & $\begin{array}{c}\text { Grain yield } \\
\left(\mathrm{kg} \mathrm{ha}^{-1}\right)\end{array}$ \\
\hline $0 \mathrm{~kg} \mathrm{ha}^{-1}$ & 0.87 & 46.7 & 0.02 & 0.09 & 1000 \\
$5 \mathrm{~kg} \mathrm{ha}^{-1}$ & 0.67 & 56.7 & 0.02 & 0.12 & 1333 \\
$10 \mathrm{~kg} \mathrm{ha}^{-1}$ & 1.67 & 112.3 & 0.04 & 0.08 & 2667 \\
$15 \mathrm{~kg} \mathrm{ha}^{-1}$ & 1.33 & 95.7 & 0.05 & 0.16 & 1800 \\
$20 \mathrm{~kg} \mathrm{ha}^{-1}$ & 1.00 & 70.0 & 0.05 & 0.16 & 1667 \\
\hline $\mathrm{LSD}(\mathrm{P}<0.05)$ & 0.63 & NS & NS & 0.04 & 999.8 \\
\hline
\end{tabular}

DMW $=$ Dry Matter Weight, NGPP $=$ Number of Grain per Panicle, RW= Root Weight

At 8 weeks after planting 15 and $20 \mathrm{~kg} \mathrm{ha}^{-1} \mathrm{Mn}$ gave the highest root weight with no significant difference between them while 0 and $10 \mathrm{~kg} \mathrm{ha}^{-1} \mathrm{Mn}$ have the least root weight which are not significantly different from each other. There was no significant difference in the root weight obtained with 0 and $5 \mathrm{~kg} \mathrm{ha}^{-1} \mathrm{Mn}$ at 8 weeks after planting. 
There was a significant response in yield parameters of rice by the application of manganese $(\mathrm{Mn})$ with the exception number of grain per panicle and root weight at 4 weeks of planting. This may be as a result of application of manganese soil content as reported by Dube et al. [37] from a field trial on rice that the plant biomass, panicle weight, grain weight, 1000-grain weight, chlorophyll $\mathrm{a}$ and $\mathrm{b}$ content and Hill reaction activity increased with increasing concentrations of Mn up to $0.55 \mathrm{mg} \mathrm{L}^{-1}$ followed by a decrease with further increase in $\mathrm{Mn}$.

The favorable effect on dry matter production might be due to higher leaf area per hill and leaf area index associated with high photosynthetic efficiency of rice plant leading to enhanced photosynthates accumulation and their translocation [38].

\section{Conclusion}

From the findings of this study, the experimental soil was low in most plant nutrients including micronutrients. The response of rice to manganese application is generally low in the growth parameters with the exception of plant height and number of tillers. However, significant differences were observed in the yield response of the crop to levels of $\mathrm{Mn}$ fertilization most especially in terms of root weight, grain yield and dry matter weight. For optimum yield of rice, $10 \mathrm{~kg} \mathrm{ha}^{-1} \mathrm{Mn}$ should be included in rice production fertilization programmes.

\section{Conflict of Interest}

The authors declare that there is no conflict of interest.

\section{References}

[1] W. Nazif, S. Perveen, I. Saleem, Status of Micronutrients in soils of District Bhimber (Azad Jammu and Kashmir), Journal of Agriculture and Biological Science. 1 (2006) 34-40.

[2] M. J. Malakouti, Zinc is a neglected element in the life cycle of plants: A review, Middle East Russian Journal of Plant Science and Biotechnology. 1(1) (2007) 1-12.

[3] G. E. J. Fisher, Micronutrients and animal nutrition and the link between the application of micronutrients to crops and animal health, Turkish Journal of Agriculture and Forestry. 32(3) (2008) 221-233.

[4] K. Diedrick, Manganese fertility in soybean production, Pioneer Hi-Bred agronomy sciences. 20(14) (2010).

[5] R. Millaleo et al., Manganese as essential and toxic element for plants transport, accumulation and resistance mechanisms, Journal of Soil Science and Plant Nutrition. 10(4) (2010) 470481.

[6] E. D. Imolehim, A. C. Wada, Meeting the Rice Production and Consumption demand of Nigeria with Improved Technologies, National cereal Research Institute, Badeggi, PMB 8, Niger State, Nigeria, 2000, pp. 1-11.

[7] J. O. Saka, Adoption of improved rice varieties among small-holder farmers in south western Nigeria, World Journal of Agricultural Sciences. 1(1) (2005) 42-49.

[8] F.A.O, Farming systems and poverty: improving farmer's livelihoods in a change world. Rome: Food and agricultural organization. (2001).

[9] S. Mustapha, Fertility status and productivity constraints of the basement complex-derived Ustults in Bauchi State, Nigeria, Journal of Agriculture Technology. 11 (2003) 11-19.

[10] G. Lombin, Evaluating the micronutrients fertility of Nigeria's semi-arid savanna soils. I. Copper and manganese, Soil Science. 135 (1983) 377-384. 
[11] G. Lombin, Evaluating the micronutrient fertility of Nigerian Semi - Arid Savanna Soils: Zinc Soils, Soil Science. 136 (1983) 42-47.

[12] G. Lombin, Evaluating the micronutrient fertility of Nigeria semi-arid savanna soils. Boron and Molybdenum, Soil Science Plant Nutrition. 13 (1985) 12-25.

[13] S. Mustapha, N. A. Loks, Distribution of available zinc, copper, iron and manganese in the fadama soils from two distinct agro ecological zones in Bauchi State, Nigeria, Journal of Environmental Science. 9(2) (2005) 22-28.

[14] C. A. Black et al., Method of soil analysis. Part-I physical and mineralogical properties, including statistics of measurement and sampling, American Society Agronomy. (1965) 677.

[15] A. L. P. Page, R. H. Miller D. R. Keeny, Methods of Soil Analysis. Agrononomy ASA, Madison, Wisconsin, USA. 9 (1982) 2.

[16] A. Walkley, C.A. Black, Acid extractable $\mathrm{Zn}$ in soil in relation to the occurrence of $\mathrm{Zn}$ deficiency symptoms of corn: A method of analysis, Soil Science Society of America Proceedings. 12 (1934) 143-148.

[17] R.H. Bray, N.T. Kurtz, Determination of total organic and available form of phosphorus in soil, Soil Science. 59 (1945) 39-45.

[18] C. A. Bouyoucos, A re-calibration of the hydrometer for making mechanical analysis of soils, Agrononomy Journal. 31 (1951) 510-513.

[19] W. L. Lindsay, W. A. Norvell, Development of DTPA soil test for zinc, iron, manganese and copper, Soil Science Society America Journal. 42 (1978) 421-428.

[20] V.O, Chude et al., Fertilizer use and management practices for Crops in Nigeria, $4^{\text {th }}$ edition. Federal Fertilizer Department, Federal Ministry of Agriculture and Rural Development. Abuja, 2012.

[21] N. Voncir, Content and profile distribution of extractable zinc ( $\mathrm{Zn}$ ) and some physicochemical properties of soil along a toposequence at Bauchi, Northern Guinea Savanna of Nigeria, International Journal of Soil Science. 3 (2008) 62-68.

[22] J. Kolo, S. Mustapha, N. Voncir, Profile distribution of some physio-chemical properties of Haplustults in Gaba District, Central Nigeria, Journal of League Research Nigeria. 10 (2009) 71-77.

[23] I. E. Esu, Detailed Soil Survey of NIHORT farm at Bunkure, Kano Sate, Nigeria. Institute for Agricultural Research, Ahmadu Bello University, Zaria, Nigeria. (1991) 32

[24] D. T. Yaro, The extent and properties of plinthite in a landscape at Zaria, Nigeria, International Journal of Soil Science. 1 (2006) 171- 183.

[25] S. Mustapha, C. C. Nnalee, Fertility and salinity/sodicity status of some fadama soils in Jos, Plateau State, Nigeria, Journal of Sustainable Development in Agriculture and Environment. 3 (2007) 96-103.

[26] S. Mustapha et al., Contents and distribution of phosphorus forms in some haplic plinthaquults in Bauchi local Government area, Bauchi state, Nigeria, International Journal of Soil Science. 2 (2007) 197-203.

[27] T. Kparmwang, W. B. Malgwi, Some available micronutrients in profiles of Ultisols and Entisols developed from sandstone in northwestern Nigeria, in: B.R. Singh (Ed.). Management of Marginal Lands in Nigeria. Proceedings of the 23rd Annual Conference of Soil Science Society of Nigeria, UDU, Sokoto, Nigeria, 1997, 245-255. 
[28] S. Mustapha, B.R. Singh, Available zinc, copper, iron and Manganese status of the basement - complex rock-derived Ultisol in Bauchi State, Nigeria: A case study. Nigeria Journal of Soil Res. 4 (2003) 35-40.

[29] J.A. Kamasho, B.R. Singh, Available copper and zinc status of some Tanzanian volcanic ash soils: A case study, Pedologie. 32 (1982) 209-224.

[30] G. B. K. Nziguheba et al., Assessment of nutrient deficiencies in maize in nutrient omission trials and long-term field experiment in the West African Savanna, Plant Soil. 314 (2009) 143-157.

[31] S. Mustapha, H.K. Mamman, N.A. Abdulhamid, Status and distribution of extractable micronutrients in Haplustults in Yamaltu-Deba Local Government Area, Gombe state, Nigeria, Journal of Soil Science and Environmental Management. 1(8) (2010) 200-204.

[32] T. Kparmwang, Inherent fertility status of upland and fadama soils in Bauchi State, Nigeria, Noma. 12 (1996) 1-7.

[33] D.U. Qin et al., Effects of interaction between manganese and cadmium on plant growth and contents of cadmium and manganese in rice, Chinese Journal of Rice Science. 24(2) (2010) 189-195.

[34] B. Prashad, J. Prashad, R. Prashad, Nutrient management for sustainable rice and wheat production in calcareous soil amended with green manuring, organic manures and zinc. Fertilizer News. 40 (1995) 39-45.

[35] P.M. Shanmugam, R. Veeraputhran, Effect of organic manure, bio fertilizers, inorganic nitrogen and zinc on growth and yield of rabi rice (Oryza sativa L.), Madras Agricultural Journal. 87(1/3) (2000) 90-93.

[36] S.R. Mousavi, Zinc in crop production and interaction with phosphorus, Aust. J. Bas. Appl. Sci. 5(9) (2011) 1503-1509.

[37] B.K. Dube, K. Neena, C. Chatterjee, Yield, physiology and productivity of rice under manganese stress, Indian Journal of Plant Physiology. 7(4) (2002) 392-395.

[38] A.K. Singh, S. Thakur, S.K. Singh, Response of rice to nitrogen and zinc application in a calcareous situation, Int. Rice Res. Notes. 29 (1995) 16-17. 